\title{
PENGARUH KUALITAS AUDIT, LIKUIDITAS, SOLVABILITAS DAN PROFITABILITAS TERHADAP OPINI AUDIT GOING CONCERN PADA PERUSAHAAN PERDAGANGAN DI BURSA EFEK INDONESIA
}

\author{
Yuni Anggraini ${ }^{1}$, Endang Sri Mulatsih ${ }^{2}$, Feronika Rosalin ${ }^{3}$ \\ E-mail : yuniangg1506@gmail.com ${ }^{1}$, endangsrimulatsih21@gmail.com² ${ }^{2}$, feronikarosalin@gmail.com ${ }^{3}$
}

\begin{abstract}
Abstrak
Perusahan-perusahaan yang ingin bertahan dan lebih maju perlu mengembangkan strategi baru. Dalam perekonomian seperti ini tidak satu pun yang selamanya aman dari persaingan, baik local maupun global. Begitu pula yang terjadi pada perusahaan di sektor industry perdagangan, jasa dan investasi yang terdaftar di Bursa Efek Indonesia. Rumusan masalah dalam penelitian ini adalah perkembangan pengaruh kualitas audit, likuiditas, solvabilitas dan profitabilitas terhadap opini audit going concern pada perusahaan perdagangan di Bursa Efek Indonesia periode 2016-2018 dilihat dari secara parsial dan simultan. Tujuan penelitian ini untuk melihat perkembangan pengaruh kualitas audit, likuiditas, solvabilitas, profitabilitas secara parsial dan simultan. Periode yang digunakan dalam penelitian ini adalah tahun 20162018. Populasi dalam penelitian ini adalah perusahaan perdagangan yang terdaftar di BEI. Pemilihan sampel menggunakan metode purposive sampling. Analisis data yang digunakan untuk menguji hipotesis adalah menggunakan teknik analisis regresi logistik. Berdasarkan hasil penelitian menunjukan bahwa penelitian menujukkan bahwa secara parsial, kualitas audit, likuiditas, dan solvabilitas tidak mempunyai pengaruh yang signifikan terhadap opini audit going concern. Sedangkan secara simultan, minimal ada satu variabel yang mempunyai pengaruh signifikan terhadap opini audit going concern.
\end{abstract}

Kata kunci : Opini Audit Going Concern, Kualitas Audit, Likuiditas, Solvabilitas, Profitabilitas

\begin{abstract}
Abstrack
Companies that want to survive and advance need to develop new strategies. In an economy like this, nothing is always safe from competition, both local and global. Likewise, companies in the trading, service and investment industry sectors listed on the Indonesia Stock Exchange. The formulation of the problem in this research is the development of the influence of audit quality, liquidity, solvency and profitability on going concern audit opinion on trading companies on the Indonesia Stock Exchange for the period 2016-2018 seen partially and simultaneously. The purpose of this study was to see the development of the influence of audit quality, liquidity, solvency, profitability partially and simultaneously. The period used in this research is 2016-2018. The population in this study are trading companies listed on the IDX. The sample selection used purposive sampling method. Data analysis used to test the hypothesis is to use logistic regression analysis techniques. Based on the results of the study, it shows that research shows that partially, audit quality, liquidity, and solvency do not have a significant effect on going concern audit opinion. Meanwhile, simultaneously, there is at least one variable that has a significant influence on going-concern audit opinion.
\end{abstract}

Keywords: Going Concern Audit Opinion, Audit Quality, Liquidity, Solvency, Profitability

\section{PENDAHULUAN}

Opini audit going concern merupakan pendapat yang dikeluarkan auditor untuk memastikan pakah perusahaan dapat mempertahankan kelangsungan hidup perusahaan yang diyakininya (dalam SPAP, 2001). Hasil audit 
laporan keuangan auditor merupakan hal yang penting bagi pemakai laporan guna mengambil langkah dalam berinvestasi.

Kuswardi (2012), hasil penelitian menunjukkan kondisi perusahaan dan kualitas audit memiliki arah positif dan berpengaruh signifikan terhadap pembelian opini audit going concern sedangkan pertumbuhan perusahaan tidak berpengaruh terhadap pemberian opini audit going concern. Murtin dan Anam (2008) hasil penelitiannya menunjukkan bahwa kualitas audit, debt default dan kondisi keuanan perusahaan berpengaruh terhadap opini audit going concern.

Setyarno dan Januarti (2006) hasil penelitiannya menunjukkan bahwa kualitas audit dan pertumbuhan perusahaan tidak berpengaruh terhadap opini audit going concern. Mustika (2008) hasil penelitiannya menunjukkan bahwa kualitas audit, debt default, oppinion shopping dan pertumbuhan perusahaan tidak berpengaruh terhadap opini audit going concern.

Rahmadona, Sukartini dan Djefris (2019), opini audit tahun sebelumnya berpengaruh terhadap opini audit going concern sedangkan ukuran perusahaan, pertumbuhan perusahaan dan solvabilitas tidak berpengaruh terhadap opini audit going concern. Sari dan Wahyuni (2014) hasil penelitiannya menunjukkan kualitas audit dan rasio solvabilitas berpengaruh positif terhadap opini audit going concern, sedangkan pertumbuhan perusahaan dan rasio likuiditas berpengaruh berpengaruh negatif opini audit going concern.

Kristiana (2012), yang mempengaruhi opini audit going concern adalah profitabilitas, likuiditas, dan pertumbuhan perusahaan. Ketiga variabel ini mempunyai pengaruh negatif terhadap opini audit going concern. Saifudin dan Trisnadi (2015) hasil penelitiannya menunjukkan bahwa likuidiats dan solvabilitas berpengaruh terhadap opini audit going concern sedangkan kondisi perusahaan, pertumbuhan perusahaan dan profitabilitas tidak berpengaruh terhadap opini audit going concern.

Noverio dan Dewayanto (2011) menjelaskan bahwa solvabilitas berpengaruh opini audit going concern. Rasio solvabilitas yang tinggi dapat berdampak buruk bagi kondisi keuangan perusahaan. Perusahaan yang memiliki rasio likuiditas dan rasio profitabilitas yang tinggi menunjukkan kinerja keuangan perusahaan yang baik.

Berdasarkan ketidakkonsistenan hasil penelitian terdahulu, maka penulis ingin meneliti kembali pengaruh kualitas audit, likuiditas, profitabilitas dan solvabilitas terhadap opini audit going concern.

\section{METODOLOGI PENELITIAN}

\section{Opini Audit Going Concern}

Opini audit going concern adalah opini yang dikeluarkan oleh auditor untuk mengevaluasi apakah ada kesangsian tentang kemampuan perusahaan untuk mempertahankan kelangsungan hidupnya (IAI,2001:SA Seksi 341). Laporan audit dengan modifikasi mengenai going concern merupakan suatu indikasi bahwa dalam penilaian auditor terdapat risiko auditee tidak dapat bertahan dalam bisnis. Dari sudut pandang auditor, keputusan tersebut melibatkan beberapa tahap analisis. Auditor harus mempertimbangkan hasil dari operasi, kondisi ekonomi yang mempengaruhi perusahaan, kemampuan membayar hutang, dan kebutuhan likuiditas di masa yang akan datang. Going concern dipakai sebagai asumsi dalam pelaporan keuangan sepanjang tidak terbukti adanya informasi yang menunjukkan hal berlawanan (contrary information). Biasanya informasi yang secara signifikan dianggap berlawanan dengan asumsi kelangsungan hidup satuan usaha adalah berhubungan dengan ketidakmampuan satuan usaha dalam memenuhi

kewajiban pada saat jatuh tempo tanpa melakukan penjualan sebagian besar aktiva kepada pihak luar melalui bisnis biasa, restrukturisasi utang, perbaikan operasi yang dipaksakan dari luar dan kegiatan serupa yang lain (IAI,2001: SA Seksi 341.1 paragraf 1 ).

\section{Kualitas Audit}

Kualitas audit dapat diartikan sebagai bagus tidaknya suatu pemeriksaan yang telah dilakukan oleh auditor. Berdasarkan Standar Profesional Akuntan Publik (SPAP) audit yang dilaksanakan auditor dikatakan berkualitas, jika memenuhi ketentuan atau standar pengauditan. Standar pengauditan mencakup mutu professional, auditor independen, pertimbangan (judgement) yang digunakan dalam pelaksanaan audit dan 
penyusunan laporan audit. Kualitas audit seharusnya berhubungan dengan pekerjaan auditor sehingga hanya atas dasar kualitas pekerjaanlah kualitas audit diukur. Kualitas memang tidak akan sama di setiap kantor akuntan, terlebih antarkantor dengan ukuran yang berbeda dan secara signifikan. Kualitas audit yang bisa diberikan oleh kantor berukuran besar yang berskala internasional dengan kantor yang hanya berskala lokal atau regional pasti akan berbeda. Kualitas auditor yang berpengalaman mengaudit di suatu industri memang akan berbeda dengan auditor yang tidak berpengalaman mengaudit di industry tersebut. Akan tetapi, hal itu tidak berarti bahwa kualitas audit atau kualitas auditor bisa diukur dengan ukuran kantor akuntan atau spesialisasi kantor akuntan (Arum, 2018:22).

\section{Likuiditas}

Likuiditas adalah rasio keuangan yang digunakan untuk mengukur kemampuan perusahaan untuk membayar hutang jangka pendeknya. Jika tingkat likuiditas suatu perusahaan tinggi, maka kinerja perusahaan tersebut akan dinilai semakin baik. Sebaliknya, jika tingkat likuiditasnya rendah, maka kinerja perusahaan tersebut akan dinilai buruk. Dengan tingkat likuiditas yang tinggi, maka suatu perusahaan bisa lebih mudah mendapatkan dukungan dari berbagai pihak seperti lembaga keuangan dan kreditur.

\section{Solvabilitas}

Solvabilitas atau leverage ratio merupakan yang menunjukkan kemampuan perusahaan untuk membayar semua utang-utangnya dengan aset yang dimilikinya jika perusahaan tersebut dilikuidasi (IAI, 2016:361). Sutrisno (2009) yang melihat solvabilitas sebagai kemampuan suatu perusahaan dalam memenuhi seluruh kewajibannya jika perusahaan dilikuidasi. Rasio solvabilitas yang tinggi dapat berdampak buruk bagi kondisi keuangan perusahaan. Semakin tinggi rasio solvabilitas, semakin menunjukkan kinerja keuangan perusahaan yang buruk dan dapat menimbulkan ketidakpastian mengenai kelangsungan hidup perusahaan.

\section{Profitabilitas}

Profitabilitas merupakan rasio keuangan yang digunakan untuk kemampuan suatu perusahaan dalam menghasilkan laba. Profitabilitas suatu perusahaan dapat dinilai melalui berbagai cara tergantung pada laba dan aktiva atau modal yang akan diperbandingkan satu dengan lainnya.

\section{Kerangka Pemikiran}

Gambar 1

Kerangka Pemikiran

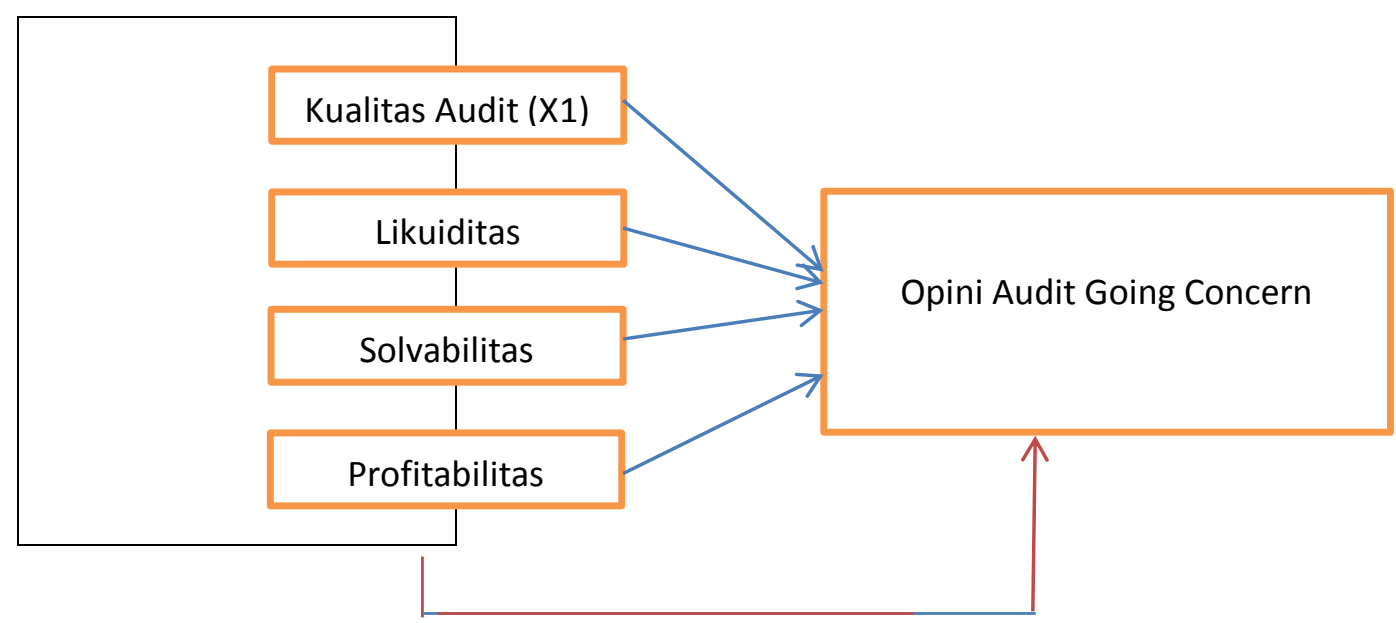

Keterangan:

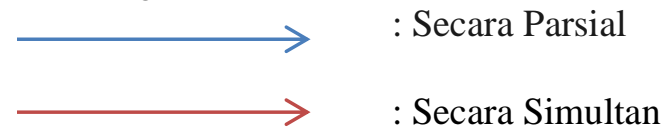




\section{METODE PENELITIAN}

\section{Sumber Data}

Dalam penelitian ini adalah Data Sekunder yang diperoleh Bursa Efek Indonesia (https://www.idx.co.id/) yaitu laporan keuangan dan annual report perusahaan perdagangan periode 2016-2018.

\section{Populasi dan Sampel Penelitian}

Populasi dalam penelitian ini ada 73 perusahaan perdagangan. Dengan teknik penarikan sampel Purposive Sampling didapat sampel sebanyak 12 perusahaan. Periode penelitian dari tahun 2016 sampai 2018 sehingga total sampel sebanyak 36 perusahaan perdagangan.

Tabel 1

Jumlah Populasi

\begin{tabular}{|l|l|}
\hline Perusahaan perdagangan & 73 \\
\hline Listing di BEI tahun 2016-2018 & $(36)$ \\
\hline Menerbitkan Laporan Keuangan tahun 2016-2018 & $(20)$ \\
\hline Laporan Keuangan dalam Rupiah & $(5)$ \\
\hline Jumlah & 12 \\
\hline Sampel $12 \times 3$ & 36 \\
\hline
\end{tabular}

\section{Metode Analisis Data}

Penelitian ini menggunakan pendekatan kuantitatif dengan menggunakan alat analisis regresi logistik.

\section{Variabel Penelitian}

Dalam penelitian ini variabel dependennya adalah opini audit going concern dan variabel independennya adalah kualitas audit, likuiditas, solvabilitas dan profitabilitas dengan persamaan regresi sebagai berikut:

$\mathrm{Y}=\mathrm{a}+\mathrm{b}_{1} \mathrm{X}_{1}+\mathrm{b}_{2} \mathrm{X}_{2}+\mathrm{b}_{3} \mathrm{X}_{3}+\mathrm{b}_{4} \mathrm{X}_{4}+\mathrm{e}$

Keterangan:

$\mathrm{Y}=$ Opini audit going concern.

$\mathrm{X}_{1} \quad=$ Kualitas audit

$\mathrm{X}_{2} \quad=$ Likuiditas

$\mathrm{X}_{3} \quad=$ Solvabilitas

$\mathrm{X}_{4} \quad=$ Profitabilitas

$\mathrm{a}=$ Konstanta

$\mathrm{b}_{1}, \mathrm{~b}_{1}, \mathrm{~b}_{1}, \mathrm{~b}_{1} \quad=$ Koefisien regresi

$\mathrm{e}=$ error

\section{Definisi Operasional}

\section{a. Opini audit going concern}

Opini audit going concern merupakan pendapat yang dikeluarkan auditor untuk memastikan apakah perusahaan dapat mempertahankan kelangsungan hidup perusahaan yang diyakininya (dalam SPAP, 2001). Opini audit going concern diberi kode 1, sedangan opini audit non going concern diberi kode 0 (Setyarno dan Januarti, 2006).

\section{b. Kualitas audit}

Kualitas audit yang baik ditunjukkan dengan perusahaan menggunakan jasa Kantor Akuntan Publik (KAP) yang mempunyai reputasi atau nama yang baik. KAP yang besar akan berusaha untuk menyajikan kualitas audit yang lebih besar dibanding dengan KAP yang kecil, KAP yang besar masuk kategori Big-4 dan KAP yang kecil masuk kategori non Big-4 (Kartika 2012) Kualitas audit diukur dengan variabel dummy apabila KAP Big- 4 diberi kode 1, sedangkan non Big-4 diberi kode 0 .

\section{c. Likuiditas}

Likuiditas adalah rasio keuangan yang digunakan untuk mengukur kemampuan perusahaan dalam membayar hutang jangka pendeknya. Dalam penelitian ini menggunakan current ratio.

Current Ratio $=\frac{\text { Aktiva Lancar }}{\text { Hutang Lancar }}$

Sumber: Murhadi ( 2013: 57)

\section{d. Solvabilitas}

Solvabilitas adalah rasio keuangan yang menunjukkan kemampuan perusahaan untuk membayar semua utang-utangnya dengan aset 
yang dimilikinya jika perusahaan tersebut dilikuidasi. Rasio solvabilitas yang digunakan adalah debt to asset Ratio (DAR).

Debt to Asset Ratio $=\frac{\text { Total Hutang }}{\text { Total Asset }}$

Sumber: Murhadi ( 2013: 61)

\section{e. Profitabilitas}

Profitabilitas adalah rasio keuangan yang digunakan untuk mengukur kemampuan perusahaan dalam memperoleh laba. Dalam penelitian ini menggunakan Net Profit Margin.

Net Profit Margin $=\frac{\text { Earning After Interest and Tax }}{\text { Revenue }}$ Sumber: Murhadi ( 2013: 64)

\section{Hipotesis}

H1 : Diduga ada pengaruh kualitas audit, likuiditas, solvabilitas, dan profitabilitas terhadap opini audit going concern pada perusahaan perdagangan yang terdaftar di Bursa Efek Indonesia secara parsial.

$\mathrm{H} 2$ : Diduga minimal ada satu varibel X (kualitas audit, likuiditas,solvabiltas, dan profitabilitas) berpengaruh terhadap opini audit going

\section{HASIL DAN PEMBAHASAN \\ Deskripsi Sampel}

a. Perkembangan Kualitas Audit

Tabel 2

Perkembangan Kualitas Audit Periode 2016-2018

\begin{tabular}{|l|c|c|c|c|}
\hline \multirow{2}{*}{ KAP } & \multicolumn{3}{|c|}{ Tahun Penelitian } & \multirow{2}{*}{ Jumlah } \\
\cline { 2 - 4 } & 2016 & 2017 & 2018 & 13 \\
\hline Big-4 & 5 & 4 & 4 & 23 \\
\hline Non Big-4 & 7 & 8 & 8 & 36 \\
\hline Total & 12 & 12 & 12 & \\
\hline
\end{tabular}

Sumber: Diolah, 2020

Dari tabel 2 dapat dilihat bahwa pada tahun 2016 dari 12 perusahaan yang dijadikan sampel, 5 perusahaan yang termasuk KAP Big-4 dan 7 perusahaan KAP non Big-4, pada tahun 2017 terdapat dari 12 perusahaan, 4 perusahaan yang termasuk KAP Big-4 dan 8 perusahaan KAP non Big-4, dan pada tahun 2018 dari 12 perusahaan, terdapat 4 perusahaan yang termasuk KAP Big-4 dan 8 perusahaan KAP non Big-4

b. Perkembangan Likuiditas
Pada Tabel 3 dapat dilihat bahwa perkembangan likuiditas selama tiga tahun (20162018) perusahaan perdagangan yang terdaftar di BEI bervariasi. Pada periode tersebut perusahaan perdagangan yang likuiditasnya cenderung meningkat adalah PT. Bintang Mitra Semestaraya,Tbk, dan PT Ramayana Lestari Sentosa, Tbk. Sedangkan perusahaan perdagangan yang likuiditasnya cenderung menurun adalah PT Ace Hardware Tbk, PT Dian Swastatika Tbk, PT. Dua Putra Utama Makmur, Tbk dan PT. Kobexindo Tractors, Tbk.

Tabel 3

Perkembangan Likuiditas Periode 2016-2018

\begin{tabular}{|l|c|c|}
\hline \multicolumn{1}{|c|}{ Nama Perusahaan } & Tahun & Likuiditas \\
\hline PT Ace Hardware Tbk & 2016 & 7,26 \\
\hline & 2017 & 7,02 \\
\hline & 2018 & 6,49 \\
\hline PT. Bintang Mitra Semestaraya, Tbk & 2016 & 1,36 \\
\hline & 2017 & 1,37 \\
\hline & 2018 & 1,64 \\
\hline PT. Industri dan Perdagangan Bintraco Dharma Tbk & 2016 & 2.02 \\
\hline & 2017 & 2.20 \\
\hline
\end{tabular}




\begin{tabular}{|l|l|l|}
\hline & 2018 & 2.15 \\
\hline PT. Colorpark Indonesia Tbk & 2016 & 3.25 \\
\hline & 2017 & 3.12 \\
\hline PT Dian Swastatika Tbk & 2018 & 2,15 \\
\hline & 2016 & 1,71 \\
\hline & 2017 & 1,68 \\
\hline PT. Dua Putra Utama Makmur, Tbk & 2018 & 1,31 \\
\hline & 2016 & 3,01 \\
\hline & 2017 & 1,79 \\
\hline PT. Hero Supermarket Tbk & 2018 & 1,70 \\
\hline & 2016 & 1,42 \\
\hline & 2017 & 1,27 \\
\hline PT. Jaya Kontruksi Manggala Pratama Tbk & 2018 & 1,36 \\
\hline & 2016 & 1,69 \\
\hline & 2017 & 1,70 \\
\hline PT. Kobexindo Tractors, Tbk. & 2018 & 1,29 \\
\hline & 2016 & 1,59 \\
\hline & 2017 & 1,42 \\
\hline PT. Matahari Departement Store Tbk & 2018 & 1,11 \\
\hline & 2016 & 1,14 \\
\hline & 2017 & 0,13 \\
\hline PT. Matahari Putra Prima Tbk & 2018 & 1,10 \\
\hline & 2016 & 1,23 \\
\hline & 2017 & 0,64 \\
\hline PT Ramayana Lestari Sentosa & 2018 & 0,85 \\
\hline & 2016 & 2,80 \\
\hline & 2017 & 2,95 \\
\hline & 2018 & 3,25 \\
\hline
\end{tabular}

\section{Sumber: Diolah, 2020}

Perusahaan perdagangan periode 2016-2018 yang likuiditasnya mengalami fluktuasi adalah PT. Industri dan Perdagangan Bintraco Dharma Tbk, PT. Colorpark Indonesia Tbk, PT. Hero
Supermarket Tbk, PT. Jaya Kontruksi Manggala Pratama Tbk, PT. Matahari Departement Store Tbk dan PT. Matahari Putra Prima Tbk

c. Perkembangan Solvabilitas

Tabel 4

Perkembangan Solvabilitas Periode 2016-2018

\begin{tabular}{|l|c|c|}
\hline Nama Perusahaan & Tahun & Solvabilitas \\
\hline PT Ace Hardware Tbk & 2016 & 0,18 \\
\hline & 2017 & 0,28 \\
\hline PT. Bintang Mitra Semestaraya, Tbk & 2018 & 0,20 \\
\hline & 2016 & 0,70 \\
\hline & 2017 & 0,71 \\
\hline PT. Industri dan Perdagangan Bintraco Dharma Tbk & 2018 & 0,75 \\
\hline & 2016 & 0,78 \\
\hline & 2017 & 0,79 \\
\hline
\end{tabular}




\begin{tabular}{|l|l|l|}
\hline PT. Colorpark Indonesia Tbk & 2016 & 0,24 \\
\hline & 2017 & 0,25 \\
\hline PT Dian Swastatika Tbk & 2018 & 0,36 \\
\hline & 2016 & 0,46 \\
\hline & 2017 & 0,50 \\
\hline PT. Dua Putra Utama Makmur, Tbk & 2018 & 0,54 \\
\hline & 2016 & 0,23 \\
\hline & 2017 & 0,32 \\
\hline PT. Hero Supermarket Tbk & 2018 & 0,33 \\
\hline & 2016 & 0,27 \\
\hline & 2017 & 0,29 \\
\hline PT. Jaya Kontruksi Manggala Pratama Tbk & 2018 & 0,37 \\
\hline & 2016 & 0,45 \\
\hline & 2017 & 0,42 \\
\hline PT. Kobexindo Tractors, Tbk. & 2018 & 0,46 \\
\hline & 2016 & 0,58 \\
\hline & 2017 & 0,67 \\
\hline PT. Matahari Departement Store Tbk & 2018 & 0,71 \\
\hline & 2016 & 0,61 \\
\hline & 2017 & 0,57 \\
\hline PT. Matahari Putra Prima Tbk & 2018 & 0,63 \\
\hline & 2016 & 0,63 \\
\hline & 2017 & 0,78 \\
\hline PT Ramayana Lestari Sentosa & 2018 & 0,76 \\
\hline & 2016 & 0,28 \\
\hline & 2017 & 0,28 \\
\hline
\end{tabular}

\section{Sumber: Diolah, 2020}

Pada Tabel 4 dapat dilihat bahwa perkembangan solvabilitas selama tiga tahun (2016-2018) perusahaan perdagangan yang terdaftar di BEI bervariasi. Pada periode tersebut perusahaan perdagangan yang solvabilitasnya cenderung meningkat adalah PT. Industri dan Perdagangan Bintraco Dharma Tbk, PT. Colorpark Indonesia Tbk, PT Dian Swastatika Tbk, PT. Dua Putra Utama Makmur, Tbk, PT.
Hero Supermarket Tbk, PT. Kobexindo Tractors, Tbk dan PT. Matahari Departement Store Tbk. Sedangkan perusahaan yang solvabilitasnya mengalami fluktuasi adalah PT Ace Hardware Tbk, PT. Bintang Mitra Semestaraya,Tbk, PT. Jaya Kontruksi Manggala Pratama Tbk dan PT. Matahari Putra Prima Tbk. PT Ramayana Lestari Sentosa, Tbk. solvabilitasnya cenderung menurun.

d. Perkembangan Profitabilitas

Tabel 5

Perkembangan Profitabilitas Periode 2016-2018

\begin{tabular}{|l|c|c|}
\hline Nama Perusahaan & Tahun & Profitabilitas \\
\hline PT Ace Hardware Tbk & 2016 & 0,19 \\
\hline & 2017 & 0,18 \\
\hline & 2018 & 0,18 \\
\hline PT. Bintang Mitra Semestaraya, Tbk & 2016 & 0,008 \\
\hline & 2017 & 0,01 \\
\hline
\end{tabular}




\begin{tabular}{|c|c|c|}
\hline & 2018 & 0,01 \\
\hline \multirow[t]{3}{*}{ PT. Industri dan Perdagangan Bintraco Dharma Tbk } & 2016 & 0,19 \\
\hline & 2017 & 0,22 \\
\hline & 2018 & 0,22 \\
\hline \multirow[t]{3}{*}{ PT. Colorpark Indonesia Tbk } & 2016 & 0,09 \\
\hline & 2017 & 0,11 \\
\hline & 2018 & 0,9 \\
\hline \multirow[t]{3}{*}{ PT Dian Swastatika Tbk } & 2016 & 0,09 \\
\hline & 2017 & 0,38 \\
\hline & 2018 & 0,13 \\
\hline \multirow[t]{3}{*}{ PT. Dua Putra Utama Makmur, Tbk } & 2016 & 0,14 \\
\hline & 2017 & 0,008 \\
\hline & 2018 & 0,008 \\
\hline \multirow[t]{3}{*}{ PT. Hero Supermarket Tbk } & 2016 & 0,008 \\
\hline & 2017 & 0,19 \\
\hline & 2018 & 0,14 \\
\hline \multirow[t]{3}{*}{ PT. Jaya Kontruksi Manggala Pratama Tbk } & 2016 & 0,12 \\
\hline & 2017 & 0,11 \\
\hline & 2018 & 0,1 \\
\hline \multirow[t]{3}{*}{ PT. Kobexindo Tractors, Tbk. } & 2016 & 0,18 \\
\hline & 2017 & 0,7 \\
\hline & 2018 & 0,8 \\
\hline \multirow[t]{3}{*}{ PT. Matahari Departement Store Tbk } & 2016 & 0,31 \\
\hline & 2017 & 0,29 \\
\hline & 2018 & 0,26 \\
\hline \multirow[t]{3}{*}{ PT. Matahari Putra Prima Tbk } & 2016 & 0,002 \\
\hline & 2017 & 0,09 \\
\hline & 2018 & 0,13 \\
\hline \multirow[t]{3}{*}{ PT Ramayana Lestari Sentosa } & 2016 & 0,8 \\
\hline & 2017 & 0,13 \\
\hline & 2018 & 0,17 \\
\hline
\end{tabular}

\section{Sumber: Diolah, 2020}

Pada Tabel 5 dapat dilihat bahwa perkembangan profitabilitas selama tiga tahun (2016-2018) perusahaan perdagangan yang terdaftar di BEI bervariasi. Pada periode tersebut perusahaan perdagangan yang profitabilitasnya cenderung meningkat adalah PT. Bintang Mitra Semestaraya,Tbk, PT. Industri dan Perdagangan Bintraco Dharma Tbk, PT. Matahari Putra Prima Tbk.dan PT Ramayana Lestari Sentosa, Tbk.
Sedangkan perusahaan yang profitabilitasnya mengalami fluktuasi adalah PT. Colorpark Indonesia Tbk, PT Dian Swastatika Tbk, PT. Hero Supermarket Tbk, dan PT. Kobexindo Tractors, Tbk. Perusahaan yang profitabilitasnya cenderung menurun adalah PT Ace Hardware Tbk, PT. Dua Putra Utama Makmur, Tbk, PT. Jaya Kontruksi Manggala Pratama Tbk dan PT. Matahari Departement Store Tbk.

e. Perkembangan Opini Audit Going Concern

Tabel 6

Perkembangan Opini Audit Going Concern Periode 2016-2018

\begin{tabular}{|l|c|c|c|c|}
\hline \multirow{2}{*}{ Opini Audit Going Concern } & \multicolumn{3}{|c|}{ Tahun Penelitian } & \multirow{2}{*}{ Jumlah } \\
\cline { 2 - 4 } & 2016 & 2017 & 2018 & \\
\hline Opini Audit Going Concern & 9 & 10 & 9 & 28 \\
\hline
\end{tabular}




\begin{tabular}{|l|c|c|c|c|}
\hline Opini Audit Non Going Concern & 3 & 2 & 3 & 8 \\
\hline Total & 12 & 12 & 12 & 36 \\
\hline
\end{tabular}

Sumber: Diolah, 2020

Dari tabel 6 dapat dilihat bahwa pada tahun 2016 dari 12 perusahaan yang dijadikan sampel, 9 perusahaan mendapat Opini Audit Going Concern dan 3 perusahaan mendapat Opini Audit Non Going Concern, pada tahun 2017 terdapat dari 12 perusahaan, 10 perusahaan mendapat Opini Audit
Going Concern dan 2 perusahaan mendapat Opini Audit Non Going Concern, dan pada tahun 2018 dari 12 perusahaan, terdapat 9 perusahaan mendapat Opini Audit Going Concern dan 3 perusahaan mendapat Opini Audit Non Going Concern.

\section{Hasil Pengujian}

Hasil pengujian regresi logistik dengan menggunakan SPSS 22 adalah sebagai berikut:

Tabel 7

Hasil Pengujian Hipotesis Analisis Parsial

\begin{tabular}{|l|c|c|}
\hline \multicolumn{1}{|c|}{ Variabel Independen } & b & Signifikansi \\
\hline Kualitas Audit & 2,329 & 0,155 \\
\hline Likuiditas & 0,006 & 0,302 \\
\hline Solvabilitas & 0,072 & 0,085 \\
\hline Profitabilitas & 0,332 & 0,042 \\
\hline Konstanta & $-6,851$ & 0,033 \\
\hline
\end{tabular}

Sumber : Data diolah dari SPSS 22

BeTabel 8

Hasil Pengujian Hipotesis Analisis Simultan

\begin{tabular}{|c|c|c|}
\hline Variabel dependen & b & Signifikansi \\
\hline Opini Audit Going Concern & 1,253 & 0,002 \\
\hline
\end{tabular}

Sumber : Data diolah dari SPSS 22

Tabel 9

Hasil Pengujian Koefisien Determinasi $\mathbf{R}^{2}$

\begin{tabular}{|c|c|c|}
\hline -2 Log likehood & $\begin{array}{c}\text { Cox \& Snell R } \\
\text { Square }\end{array}$ & Nigelkerke R Square \\
\hline 19,832 & 0,399 & 0,610 \\
\hline
\end{tabular}

Sumber : Data diolah dari SPSS 22

Pembahasan

Pengaruh Kualitas Audit terhadap Opini Audit Going Concern

Kualitas audit yang baik ditunjukkan dengan perusahaan menggunakan jasa Kantor Akuntan Publik (KAP) yang mempunyai reputasi atau nama yang baik. KAP yang besar akan berusaha untuk menyajikan kualitas audit yang lebih baik dibanding dengan KAP yang kecil, KAP yang besar masuk kategori Big-4 dan KAP yang kecil masuk kategori non Big-4.
Hasil pengujian secara parsial menunjukkan bahwa kualitas audit tidak berpengaruh terhadap opini audit going concern. Hal ini sejalan dengan penelitian Setyarno dan Januarti (2006) dan Mustika (2008) bahwa kualitas audit tidak berpengaruh terhadap penerimaan opini audit going concern.

Sari dan Wahyuni (2014), Kuswardi (2012) dan Murtin dan Anam (2008) hasil penelitiannya menunjukkan kualitas audit berpengaruh positif terhadap pemberian opini audit going concern. 


\section{Pengaruh Likuiditas terhadap Opini Audit Going Concern}

Likuiditas menggambarkan kemampuan perusahaan untuk memenuhi kewajiban jangka pendeknya dengan asset lancar yag dimilikinya. Hal ini dapat dijelaskan bahwa makin kecil likuiditas, perusahaan kurang liquid karena banyak kredit macet sehingga opini audit harus memberikan keterangan mengenai going concern.

Hasil pengujian secara parsial menunjukkan bahwa likuiditas tidak berpengaruh terhadap opini audit going concern. Kondisi ini terjadi karena perusahaan dengan posisi keuangan yang tinggi, akan tetapi memiliki perencanaan dalam memperbaiki operasi perusahaan dan kemampuan untuk mengelola keuangan dengan baik, serta mampu menyajikan laporan keuangan yang wajar. Oleh karena itu, rasio likuiditas kurang dipertimbangkan auditor dalam memberikan opini audit going concern.

Hasil penelitian ini tidak sejalan dengan Saifudin \&Trisnawati (2015) yang menyatakan bahwa likuiditas berpengaruh terhadap opini audit going concern. Sedangkan Sari \& Wahyuni (2014) dan Kristiana (2012) hasil penelitiannya menunjukkan bahwa rasio likuiditas berpengaruh negatif terhadap opini audit going concern (Kristiana, 2012)

\section{Pengaruh Solvabilitas Terhadap Opini Audit Going Concern}

Solvabilitas (leverage) adalah kemampuan perusahaan untuk membayar semua utang-utangnya dengan asset yang dimilikinya jika perusahaan tersebut dilikuidasi. Semakin tinggi nilai solvabilitas, maka perusahaan dikatakan mampu memenuhi kewajiban keuangannya meskipun perusahaan tersebut sedang mengalami laba negatif. Karena itu semakin besar kemungkinan auditor untuk memberikan opini going concern.

Hasil penelitian menunjukkan rasio solvabilitas tidak berpengaruh terhadap opini audit going concern Kondisi ini terjadi karena perusahaan dengan posisi keuangan yang tinggi, akan tetapi memiliki perencanaan dalam memperbaiki operasi perusahaan dan kemampuan untuk mengelola keuangan dengan baik, serta mampu menyajikan laporan keuangan yang wajar. Oleh karena itu, rasio solvabilitas kurang dipertimbangkan auditor dalam memberikan opini audit going concern. Hasil penelitian sejalan dengan Rahmadona, Sukartini dan Djefris (2019) yang menyatakan bahwa solvabilitas tidak berpemngaruh terhadap opini audit going concern. Sedangkan Sari dan Wahyuni (2014), Noverio (2011) dan Saifudin \& Trisnawati (2015), hasil penelitian menunjukkan rasio solvabilitas berpengaruh terhadap opini audit going concern.

\section{Pengaruh Profitabilitas Terhadap Opini Audit Going Concern}

Profitabilitas yang menggambarkan kemampuan perusahaan untuk memperoleh laba melalui semua kemampuan, dan sumber yang ada seperti kegiatan penjualan, kas, modal, jumlah karyawan dan sebagainya. Perusahaan dengan tingkat profitabilitas tinggi mengindikasikan bahwa perusahaan tersebut mampu menjalankan usahanya dengan baik sehingga dapat mempertahankan kelangsungan hidupnya. Dengan kata lain semakin tinggi tingkat profitabilitas maka semakin rendah pula kemungkinan pemberian opini audit going concern oleh auditor. Sebaliknya, perusahaan yang memiliki tingkat profitabilitas rendah maka cenderung akan mendapatkan opini audit going concern.

Hasil penelitian menunjukkan bahwa profitabilitas mempunyai pengaruh signifikan terhadap opini audit going concern perusahaan perdagangan yag terdaftar di Bursa Efek Indonesia. Kondisi ini terjadi karena perusahaan dengan laba perusahaan sebelum pajak yang rendah, akan tetapi memiliki perencanaan dalam memperbaiki operasi perusahaan dan kemampuan untuk mengelola laba perusahaan yang baik, serta mampu menyajikan laporan keuangan yang wajar. Oleh karena itu, profitabilitas dipertimbangan oleh auditor dalam memberikan opini audit going concern.

Hasil penelitian sejalan dengan Kristiana (2012) yang menunjukkan rasio profitabilitas berpengaruh negatif terhadap opini audit going concern dan bertolak belakang dengan Saifudin \& Trisnawati (2015) yang hasil penelitiannya menunjukkan rasio profitabilitas tidak berpengaruh terhadap opini audit going concern.

\section{KESIMPULAN DAN SARAN KESIMPULAN}


1. Secara parsial hasil penelitian menunjukkan bahwa kualitas audit, likuiditas, dan solvabilitas tidak berpengaruh terhadap opini audit going concern. Sedangkan Profitabilitas berpengaruh terhadap opini audit going concern.

2. Secara simultan hasil penelitian menunjukkan minimal ada satu variabel $\mathrm{X}$ (kualitas audit, likuiditas, solvabilitas, profitabilitas) yang berpengaruh terhadap opini audit going concern.

3. Koefisien determinasi $\left(R^{2}\right)$ menunjukkan bahwa kualitas audit, likuiditas, solvabilitas, dan profitabilitas mempengaruhi opini audit going concern sebesar 0,399 atau 39,9\% sedangkan sisanya $60,1 \%$ dipengaruhi oleh faktor-faktor lainnya diluar variabel penelitian.

\section{SARAN}

1. Bagi perusahaan/ Manajer perusahaan harus memperhatikan hal-hal yang berkaitan dengan keuangan perusahaan agar dapat menghasilkan laporan keuangan dengan menyajikan opini wajar tanpa pengecualian dan tanpa opini audit going concern dengan menyajikan laporan keuangan secara lengkap dan mencerminkan kondisi perusahaan yang sebenarnya.

2. Bagi investor, sebaiknya memperhatikan perusahaan dapat mempertahankan kelangsungan hidup perusahaan sebagai bahan pertimbangan sebelum memberikan pinjaman dengan jumlah yang besar.

3. Bagi peneliti selanjutnya, dapat digunakan beberapa variabel lain yang belum diteliti misalnya (ukuran perusahaan, pertumbuhan perusahaan, kondisi keuangan, leverage, dan lain-lain). Diharapkan penelitian selanjutnya menggunakan jarak waktu yang lama dalam mengukur opini

4. audit going concern, dan menggunakan studi empiris agar seluruh perusahaan dapat diteliti dan menjadi informasi yang relevan bagi para pengguna informasi

\section{DAFTAR PUSTAKA}

Ardiningsih, Arum. 2015 "Audit Laporan Keuangan" Bumi Aksara: Surabaya
Arisinta, Oktaviana. 2013.” Pengaruh Kompetensi, Independensi, Time Budget Pressure dan Audit Fee Terhadap Kualitas Audit Pada Kantor Akuntan Publik di Surabaya". Jurnal Ekonomi dan Bisnis Tahun XXIII, No. 3

Ginting, Suriani dan Linda Suryana. 2014." Analisis Faktor-Faktor yang Mempengaruhi Opini Audit Going Concern Pada Perusahaan Manufaktur di Bursa Efek Indonesia". Jurnal Wira Ekonomi Mikroskil Volume 4, No. 02

Kartika, Andi. 2012." Pengaruh Kondisi Keuangan dan Non Keuangan Terhadap Penerimaan Opini Audit Going Concern Pada Perusahaan Manufaktur di BEI”. Dinamika Akuntansi, Keuangan dan Perbankan, Vol. 1, No. 1 Kasmir. 2012. Analisis Laporan Keuangan. Jakarta: PT. RajaGrafindo Persada

Kristiana. Ira. 2012.” Pengaruh Ukuran Perusahaan, Profitabilitas, Likuiditas, Pertumbuhan Perusahaan Terhadap Opimi Audit Going Concern Pada Perusahaan Manufaktur yang Terdaftar di Bursa Efek Indonesia". Berkala Ilmiah Mahasiswa Akuntansi- Vol. 1, No. 1

Kuswardi, Hans Juniarto. 2012.” Pengaruh Kondisi Keuangan, Pertumbuhan Perusahaan dan Kualitas Audit Terhadap Pemberian Opini Audit Going Concern Pada Perusahaan Whosale and Retail Trade di Bursa Efek Indonesia". Jurnal Ilmiah Mahasiswa Akuntansi- Vol. 1, No.2

Mulyadi, 2009. Akuntansi Biaya. Yogyakarta: STIE YPKPN

Murtin, Alex dan Choirul Anam. 2008." Pengaruh Kualitas Audit, Debt Default dan Kondisi Perusahaan Terhadap Penerimaan Opini Audit Going Concern". Jurnal Akuntansi dan Investasi Vol. 9, No. 2, hal: 197-207

Mustika, Vita. 2017." Pengaruh Kualitas Audit, Dept Default, Opinion Shopping danPertumbuhan Perusahaan Terhadap Penerimaan Opini Audit Going Concern Pada Perusahaan Manufaktur". Fakultas Ekonomi Universitas Riau

Noverio. 2011." Analisis Pengaruh Kualitas Auditor, Likuiditas, Profitabilitas, dan 
Solvabilitas Terhadap Opini Audit Going Concern pada Perusahaan Manufaktur yang Terdaftar di Bursa Efek Indonesia". Skripsi Universitas Di PonegoroRahmadona,

Suci. Sukartini, dan Dedy Djefris. 2019." FaktorFaktor yang Mempengaruhi Opini Audit Going Concern". Akuntansi Manajemen Vol. 14, No.1

Rosalin, F. (2015). Pengaruh Kualitas Audit, Kelalaian Membayar Hutang, Pergantian Auditor terhadap Penerimaan Opini Audit Going Concern pada Perusahaan Manufaktur yang Terdaftar di Bursa Efek Indonesia. Jurnal Ekonomi dan Bisnis (JENIUS), 5(3), 201-218.

Saifudin, Aris dan RinaTrisnawati. 2015."Prngaruh Ukuran Perusahaan, Profitabilitas, Likuiditas, Solvabilitas dan Pertumbuhan Perusahaan Terhadap Opini Audit Going Concern". Universitas Muhammadiyah Surakarta

Sari, Dewi Ratna dan Sri Wahyuni. 2014."Pengaruh Kualitas Audit, Pertumbuhan Perusahaan, Likuiditas, dan Solvabilitas Terhadap Opini Audit Going Concern Pada Perusahaan Manufaktur yang Terdaftar di Bursa Efek Indonesia 2011-2013". Fakultas Ekonomi Universitas Muhammadiyah Purwokerto

Setyarno, Eko Budi dan Indira Januarti. 2006." Pengaruh Kualitas Audit, Kondisi Keuangan Perusahaan, Opini Audit Tahun Sebelumnya, Pertumbuhan Perusahaan Terhadap Opini Audit Going Concern". Universitas Diponegoro

Simanjuntak, P. (2008). Pengaruh Time Budget Pressure Dan Resiko Kesalahan Terhadap Penurunan Kualitas Audit (Reduced Audit Qaulity)(Studi Empiris Pada Auditor Kap Di Jakarta) (Doctoral dissertation, Program Sarjana Universitas Diponegoro).

Sugiyono. 2019. Metode Penelitian Kuantitatif, Kualitatif, dan R\&D. Bandung: Alfabeta

Sukrisno, A., \& Estralita, T. (2014). Akuntansi perpajakan, Edisi 3. Jakarta: Salemba Empat.
Tim Penyusun IAI Sumsel. 2016. Pengantar Akuntansi (Berbasis SAK ETAP) Edisi Revisi 1. Palembang: IAI

Tuanakotta, T. M. (2015). Audit kontemporer. Jakarta: Salemba Empat. https://www.idx.co.id/Pengaruh Kualitas Audit, Likuiditas, Solvabilitas, dan Profitabilitas Terhadap Opini Audit Going Concern Pada Perusahaan Perdagangan di Bursa Efek Indonesia (30 April 2020)

https://en.wikipedia.org/wiki/Big_Four_auditors,2 008 (20 Juni 2020) 